\section{A participatory assessment to identify strategies for improved cervical cancer prevention and treatment in Bolivia}

\author{
Ilana G. Dzuba, ${ }^{1}$ \\ Ruth Calderón, ${ }^{2}$ Siri Bliesner, ${ }^{3}$ \\ Silvana Luciani, ${ }^{4}$ \\ Fernando Amado, ${ }^{5}$ \\ and Martha Jacob ${ }^{1}$
}

Cervical cancer remains a leading cause of death for women in many countries of the world. In Latin America and the Caribbean, cervical cancer has become the primary cause of cancer-related deaths among women despite the introduction of screening programs more than 30 years ago. Each year in Latin America and the Caribbean 52000 new cases are diagnosed, and 25000 women die of the disease (1). Bolivia has one of the highest cervical cancer incidence rates in the Americas (58.1/100 000 women) (2). An estimated 661 deaths per year in Bolivia are attributed to cervical cancer, equivalent to an agestandardized mortality rate of 22.2/100 000. This compares with 7.6/100 000 in Argentina and 12/ 100000 for all of South America. These statistics are particularly noteworthy given that cervical cancer can be prevented by the timely identification and treatment of precancerous lesions $(3,4)$.

Bolivia is one of the poorest countries in South America. Some $70 \%$ of Bolivians live in poverty, with limited access to adequate housing, sanitation, education, and health care. Surveys indicate that the public sector in Bolivia provides health care for $40 \%-60 \%$ of the population, and performs $70 \%$ of all the Pap smears done in the country for cervical cancer screening $(5,6)$.

Various efforts related to cervical cancer prevention in Bolivia have yet to result in an appreciable decrease in morbidity and mortality from the disease. These efforts have included Pap smear screening, creating the Component for the Detection and Control of Women's Cancer (Componente de Detección y Control del Cáncer de la Mujer) (the "Women's Cancer Component") as a unit within the Ministry of Health and Social Welfare (MHSW) (Ministerio de Salud y Previsión Social), and developing national clinical norms for the prevention of cervical cancer. To identify the obstacles that have impeded the effectiveness of cervical cancer prevention, three organizations joined together in 2001 to coordinate an assessment of the existing cervical cancer prevention and treatment services and the development of appropriate intervention strategies. The three groups were the Women's Cancer Component, EngenderHealth (an international reproductive health organization based in New York City), and the Pan American Health Organization. These groups adapted the World Health Organization (WHO) three-stage "Strategic Approach" for strategic planning and reproductive health policy and program development $(7,8)$ in order to de- 
velop evidence-based recommendations for interventions that could strategically enhance cervicalcancer-related services and community outreach, and thereby reduce cervical cancer rates in Bolivia. The results of the Bolivia assessment could be used to inform programming and policy by identifying management, technological, sociocultural, and economic issues that affect the quality of services and respect for clients' rights. This article reports on the findings from the assessment phase of the Strategic Approach process carried out with cervical cancer prevention and treatment services in Bolivia.

\section{METHODOLOGY}

The methodology employed was an adaptation of the first stage of WHO's three-stage Strategic Approach. The first stage itself included three parts: (1) a literature review, (2) qualitative research, and (3) development of recommendations for policy, programming, and research.

\section{Literature review}

In order to assess the current status of cervical cancer prevention and treatment services and to identify gaps in available information in Bolivia, during March through December 2001 a consulting anthropologist compiled country-specific morbidity and mortality statistics, information from available secondary sources on cervical cancer prevention and treatment, and details about Bolivia's sociodemographic, political, and economic context. The anthropologist reviewed general sources and materials identified through an Internet-based literature search and interviews with informants. Literature from the Government of Bolivia, nongovernmental organizations (NGOs), and national and international research centers were included in the review. Also, in collaboration with the manager of the Women's Cancer Component and the president of the Cancer Registry of La Paz, a list of key incountry individuals and institutions related to cervical cancer prevention was developed. Through these contacts, additional documentation and published literature were identified and then reviewed. Ultimately, information from all relevant sources was compiled into one text.

\section{Qualitative research}

The literature review generated questions to explore concerning the interactions among women, health services and providers, and the currently
FIGURE 1. The four departments of Bolivia (Cochabamba, La Paz, Potosí, Santa Cruz) where the assessment of cervical cancer prevention and treatment was carried out, 2001-2002

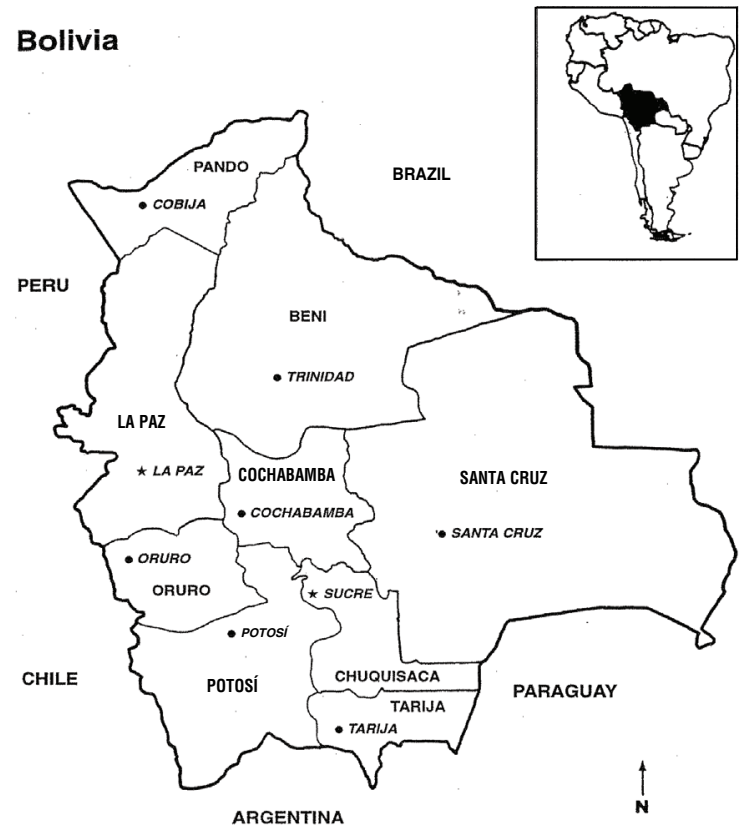

used prevention and treatment technologies. A multidisciplinary team of 15 departmental health authorities, providers, program managers, community advocates, social scientists, and local and international researchers conducted fieldwork (in-depth interviews with stakeholders and observations of health services) in January and February 2002. Prior to the fieldwork, the team was oriented to qualitative research methods, the Strategic Approach, and the results of the literature review. The team also devised three strategic questions to guide instrument development, data collection, and analysis: (1) Is it necessary to improve the current information system and cancer registry for the prevention, diagnosis, and treatment of cervical cancer? (2) Is it necessary to introduce new interventions for screening, diagnosis, and treatment of precancerous cervical lesions? (3) Is it necessary to improve the existing services for the management of cervical cancer?

Fieldwork was conducted in rural, urban, and periurban areas of four of the nine departments of Bolivia. The four were Cochabamba, La Paz, Potosí, and Santa Cruz (Figure 1). These departments were selected purposefully to include the country's three geographic and ecological zones and because they offered a range of cervical cancer prevention and treatment services. Potosí was included because of its disproportionately high rate of cervical cancer (93.5/100 000, vs. the national rate of 58.1/100 000).

The research team divided in two, with each group covering two departments over a period of 
two weeks. Existing clients of health facilities, public and private sector health facility personnel, laboratory personnel, program managers, community members, community leaders and authorities, and other stakeholders were selected to participate in the assessment by convenience and snowball sampling. These informants' perspectives on cervical cancer and its prevention, barriers to and facilitators of services, and sociocultural norms were collected through semistructured in-depth interviews based on six interview guides, which corresponded to respondent type. The interview guides were developed by the 15-member research team, based on international standards for cervical cancer prevention and treatment.

The fieldwork interviews were conducted individually or in small groups (three to five persons), and the interviewer recorded written notes in a field notebook. Prior to all interviews, respondents granted oral consent for their involvement in the study, after receiving an explanation of the objectives, interview procedures, and participants' rights.

Direct nonparticipant observations of facilities and provision of services provided data about infrastructure and aspects of quality of care. Observations were performed in facilities where cervical cancer prevention and/or treatment services are available, including cytopathology laboratories. Three observation guides (for laboratories, health care sites, and client-provider interaction) identified the physical characteristics (e.g., cleanliness, equipment and supplies, and infection prevention) and the characteristics of interpersonal communication to be examined.

The data from the interviews and the observations were analyzed continuously during the fieldwork at daily team meetings, and again following completion of the fieldwork. As the primary aim of the Strategic Approach is to improve quality of services and attention to the community, the team coded and analyzed the data according to eight internationally accepted aspects of quality of care $(9,10)$ : (1) access to services; (2) organization of services; (3) supervision and monitoring; (4) infrastructure, equipment, and supplies; (5) information system and cancer registry; (6) training and professional development; (7) knowledge and experience of health personnel; and (8) knowledge and information sources of clients and community members. Common themes and recurring issues were identified, and the salient points were drawn into conclusions.

\section{Development of recommendations}

Once the results from the literature review and qualitative research were compiled, MHSW officials, program managers, oncologists, gynecologists, cytologists, pathologists, and local NGO representatives from all departments of the countryincluding those not visited during the fieldworkwere convened at a two-day technical input workshop. These experts reviewed the assessment results and conclusions, identified evidence-based priorities, and, in small groups, reached consensus on recommendations for additional research, policy development, and programmatic interventions.

\section{FINDINGS}

\section{Literature review}

The literature review yielded 53 references that were included in the final report about the sociodemographic, political, and economic context in which Bolivia is situated; 16 of the 53 referenced items addressed the impact of cervical cancer on the country's female population. Bolivia's health system is divided into the public sector-comprised of the MHSW health services and the social security health services-and the private sector, which includes NGOs and private clinics. The MHSW is responsible for developing national norms and policies for the public sector. However, administration and provision of health services is decentralized and is the responsibility of the respective Departmental Health Service (Servicio Departamental de Salud) of each of the nine departments.

Cytology-based (Pap smear) screening was introduced in Bolivia's public sector in 1988 (11), and cervical cancer detection activities were initiated in the cities of La Paz, Santa Cruz, and Sucre the following year. In 1989 the MHSW established the Women's Cancer Component, which now functions within the National Program of Sexual and Reproductive Health (Programa Nacional de Salud Sexual y Reproductiva). The Women's Cancer Component is staffed by a single person, who is responsible for developing, administering, and supervising national programs for the prevention and treatment of women's cancer, including cervical cancer. That person also provides technical assistance to and coordinates with the director of the Sexual and Reproductive Health Program in each department in order to strengthen the implementation of national norms, training programs, and community-focused information and education. ${ }^{6}$

In 2001 the Women's Cancer Component developed the National Norms, Regulations, Protocols

6 Bolivia, Ministerio de Salud y Previsión Social; EngenderHealth; Pan American Health Organization. Evaluación de la situación de cáncer de cuello uterino en Bolivia: revisión bibliográfica [unpublished report]. La Paz, December 2001. 
TABLE 1. Cervical cancer prevention and treatment services that should be available in public sector facilities, according to Government-issued norms, Bolivia, 2001-2002

\begin{tabular}{|c|c|c|}
\hline $\begin{array}{l}\text { Level of health care } \\
\text { facilities }\end{array}$ & Type of health care facilities & $\begin{array}{l}\text { Cervical cancer prevention and treatment } \\
\text { services that should be available at each level } \\
\text { of care, according to Ministry of Health and } \\
\text { Social Welfare norms }\end{array}$ \\
\hline Primary $^{a}$ & $\begin{array}{l}\text { Health posts and health centers } \\
\text { (outpatient) }\end{array}$ & $\begin{array}{l}\text { Pap screening, transport of samples to labora- } \\
\text { tories, referral of suspicious cases, follow-up }\end{array}$ \\
\hline Secondary & $\begin{array}{l}\text { District hospitals (outpatient and } \\
\text { inpatient) }\end{array}$ & $\begin{array}{l}\text { Pap screening, transport of samples to labora- } \\
\text { tories, referral of suspicious cases, follow-up, } \\
\text { diagnosis, and treatment of precancerous } \\
\text { lesions in a few facilities }\end{array}$ \\
\hline Tertiary & $\begin{array}{l}\text { Specialized hospitals, maternity } \\
\text { hospitals, and pathology } \\
\text { laboratories }\end{array}$ & $\begin{array}{l}\text { Main referral centers for screening, diagnosis, } \\
\text { and treatment of precancerous lesions and } \\
\text { cancer; centralized laboratories process and } \\
\text { analyze all Pap smears and biopsies, and pro- } \\
\text { vide results to respective facilities }\end{array}$ \\
\hline $\begin{array}{l}\text { Oncology centers } \\
\text { (including radiotherapy) }\end{array}$ & Specialized hospitals & $\begin{array}{l}\text { Screening, diagnosis, and treatment of pre- } \\
\text { cancerous lesions and cancer }\end{array}$ \\
\hline
\end{tabular}

and Procedures for the Detection and Control of Cervical Cancer (Norma Nacional, Reglas, Protocolos y Procedimientos para la Detección y Control del Cáncer de Cuello Uterino) to establish standards for the early detection and treatment of precursor lesions and cancer in women ages $25-49$ years, and thus to reduce morbidity and mortality. The norms stipulate the objective of achieving $80 \%$ screening coverage of the target population. Other objectives include creating awareness about the importance of periodic screening and strengthening the technical and management capabilities of the public sector health system, specifically the MHSW, in order to ensure that quality cervical cancer prevention and treatment services are offered (11). At the time of the writing of this article, copies of these norms could not be found in MHSW health facilities since the norms had never been disseminated. The norms direct that cervical cancer screening and, at a minimum, referral for treatment of precancerous lesions and cancer, should be available at primary, secondary, and tertiary levels of MHSW health facilities (Table 1).

Since 1970 the private sector has implemented activities to prevent cervical cancer in Bolivia. NGOs that work in sexual and reproductive health have incorporated screening into their clinical services, and the groups refer clients with abnormal Pap smears to nearby oncology units for confirmatory diagnosis and, if necessary, treatment. Table 2 shows a summary of screening and referral services in the public and private sectors.

The literature review confirmed the dearth of available literature and statistics about cervical can- cer in Bolivia. The literature review also indicated the need for further research into systematic constraints and peoples' perceptions.

\section{Qualitative research}

A total of 583 interviews were conducted with stakeholders. Interviews were done with: 92 clients at service delivery sites; 114 community members in public settings; $284 \mathrm{MHSW}$, private, and social security health facility personnel; 2 traditional healers; 75 community leaders and authorities; and 16 medical and nursing university staff and students (Table 3 ). A total of 56 facility observations were performed, and 14 client-provider interactions were recorded. Our results are presented in the following subsections according to the eight internationally accepted quality of care analysis codes mentioned earlier.

Access to services. In the public sector, as a part of the Seguro Básico de Salud (Basic Health Insurance), free cervical cancer prevention services were authorized for all women between the ages of 25 and 49 , while other women had to pay. (In December 2002, after this study had been completed, the Basic Health Insurance was abolished and replaced by a new policy that prioritizes maternal and child health. The new Seguro Universal Materno Infantil (Universal Maternal/Infant Insurance) provides free maternity and postnatal care for women, as well as child health services for children less than five years old, but limits free cervical cancer preven- 
TABLE 2. Pap-based screening services and referral services in the public sector and in the private sector in Bolivia, 2001

\begin{tabular}{|c|c|c|}
\hline $\begin{array}{l}\text { Sector/Level } \\
\text { (Type of facility) }\end{array}$ & Providers & $\begin{array}{c}\text { Referral/treatment centers used for } \\
\text { management of abnormal Pap smears }\end{array}$ \\
\hline \multicolumn{3}{|l|}{ Public sector } \\
\hline $\begin{array}{l}\text { MHSW primary (health centers, } \\
\text { health posts) }\end{array}$ & $\begin{array}{l}\text { General practitioners, nurses, or } \\
\text { nurse auxiliaries }\end{array}$ & Tertiary level or oncology hospitals \\
\hline MHSW secondary (district hospitals) & General practitioners, gynecologists & Tertiary level or oncology hospitals \\
\hline MHSW tertiary (specialty, oncology) & Gynecologists/Oncologists & Gynecology/Oncology units \\
\hline Social security clinics and hospitals & Gynecologists & Oncology hospitals \\
\hline \multicolumn{3}{|l|}{ Private sector } \\
\hline NGO clinics ${ }^{d}$ & General practitioners & Oncology hospitals \\
\hline Private clinics & Gynecologists/Oncologists & $\begin{array}{l}\text { Treated on-site or referred to } \\
\text { oncology hospitals }\end{array}$ \\
\hline \multicolumn{3}{|c|}{$\begin{array}{l}\text { Source: Sistema Nacional de Información en Salud, } 2001(6) \text {. } \\
\text { a Public sector facilities provide } 70 \% \text { of the Pap smears in Bolivia, and private sector facilities provide the other } 30 \% \text {. } \\
\text { b Pap screening was not available in some rural primary care facilities due to absence of trained personnel. In these cases, patients were referred to } \\
\text { other, higher-level facilities for screening. } \\
\text { c MHSW = Ministry of Health and Social Welfare. } \\
\text { d NGO = nongovernmental organization. }\end{array}$} \\
\hline
\end{tabular}

tion services to only women who are pregnant and up to six months postpartum (12)). The MHSW policy of providing free services to women in a broad age group helped to overcome previous financial barriers to prevention services for many women. Although mandated by national policy, both women and providers were often unaware that cervical cancer prevention services were available at no cost to eligible women. Pap smears were available at nearly all levels of public and private sector facilities, although the personnel at some primary level MHSW health posts and centers in rural areas were not trained in cervical sampling (Table 2).

A centralized MHSW cytology laboratory is available in eight of the country's nine departments. Pando, the one department without its own cytology laboratory, sends all of its Pap smears to the city of La Paz for analysis. Every MHSW health facility in each of the nine departments is assigned to one of these eight labs. The social security lab in the city of La Paz processes most of the samples from social security centers and clinics (with the exception of Chuquisaca, Cochabamba, and Santa Cruz). Private cytology labs also exist and are used by public and private providers alike. Because of reportedly slow turn-around times and/or lack of trust in the analysis done at some MHSW labs, some providers at MHSW facilities interviewed prefer to use private labs.

Colposcopy (a confirmatory diagnostic test for cervical abnormalities) and treatment for precancerous lesions are not readily available in all departments due to a lack of trained and experienced personnel as well as equipment shortages. In the departments where these services are available, they can only be obtained in some public sector reference hospitals, oncology institutes, and a few private clinics in urban areas. Because colposcopy and precancer treatment are not available in the department of Potosí, women from that department who have abnormal Pap smears are often referred for management to Sucre, the capital city of the neighboring department of Chuquisaca. Treatment for cervical cancer is offered at four oncology units in the country, in the cities of La Paz, Santa Cruz, Cochabamba, and Sucre. These oncology units do not have systems to offer palliative care for women with terminal cervical cancer, although hospital staff at two of the sites are attempting to address this need.

Clients and community members provided extensive information about their experiences accessing cervical cancer screening and treatment for precancerous conditions. These persons commented that personal interaction with providers is particularly important and that they prefer providers who take the time to talk, explain procedures, and respond to questions. They described a number of obstacles that hinder their receiving appropriate and thorough care. Frequently, a shortage of trained providers or nonfunctioning equipment requires that women be referred to the more costly private sector for screening or treatment of precancerous conditions, for which the individual women must bear the cost. Some women reported that they have gone to the fee-for-service private clinics for Pap smears because of experiences at public health facilities with poor hygiene, unfriendly providers, a lack of continuity of care, long delays for services, and lost screening results. For example, in a qualitative interview, one woman from the department 
TABLE 3. People interviewed and number of interviews and observations completed in assessment of cervical cancer prevention in Bolivia, 2001-2002

\begin{tabular}{|c|c|}
\hline $\begin{array}{l}\text { Location of interviews/ } \\
\text { Persons interviewed }\end{array}$ & $\begin{array}{c}\text { No. of interviews } \\
\text { and observations } \\
\text { completed }\end{array}$ \\
\hline \multicolumn{2}{|l|}{ In the community } \\
\hline Women & 55 \\
\hline Men & 37 \\
\hline Community leaders & 15 \\
\hline Representatives of community groups & 7 \\
\hline \multicolumn{2}{|l|}{$\begin{array}{l}\text { Public sector health facilities (Ministry of Health } \\
\text { and Social Welfare and social security) }\end{array}$} \\
\hline General practitioners/Gynecologists & 62 \\
\hline Oncologists & 2 \\
\hline Radiotherapists & 1 \\
\hline Nurses & 33 \\
\hline Nurse auxiliaries & 20 \\
\hline Social workers & 9 \\
\hline Facility administrators & 4 \\
\hline Statisticians & 15 \\
\hline Midwives & 1 \\
\hline Clients & 92 \\
\hline $\begin{array}{l}\text { Observations of interaction between health } \\
\text { care provider and client }\end{array}$ & 14 \\
\hline Observations of facility infrastructure & 56 \\
\hline \multicolumn{2}{|l|}{$\begin{array}{l}\text { Private sector health facilities (private clinics, } \\
\text { nongovernmental organization clinics, volunteer } \\
\text { organizations, and pharmacies) }\end{array}$} \\
\hline Directors & 11 \\
\hline Medical doctors & 11 \\
\hline Nurses & 9 \\
\hline Nurse auxiliaries & 3 \\
\hline Communications specialists & 3 \\
\hline Social workers/Counselors/Psychologists & 7 \\
\hline Pharmacists & 4 \\
\hline $\begin{array}{l}\text { Others (statisticians, facility administrators, } \\
\text { receptionists, educators) }\end{array}$ & 5 \\
\hline \multicolumn{2}{|l|}{ Laboratories } \\
\hline Biotechnicians/Cytologists/Cytotechnicians & 10 \\
\hline Pathologists & 2 \\
\hline Lab technicians & 2 \\
\hline \multicolumn{2}{|l|}{ Health and political authorities } \\
\hline Prefects/Heads of human development & 6 \\
\hline Mayors/Directors of health in the mayor's office & 10 \\
\hline Directors of Departmental Health Service/ & \\
\hline Health program managers & 18 \\
\hline $\begin{array}{l}\text { Heads of Sexual and Reproductive Health } \\
\text { programs }\end{array}$ & 9 \\
\hline Directors of districts and health services & 24 \\
\hline Coordinators of Basic Health Insurance & 8 \\
\hline \multicolumn{2}{|l|}{ Universities } \\
\hline Directors of medical/nursing schools & 8 \\
\hline Directors of nurse auxiliary schools & 2 \\
\hline Medical/Nursing students & 6 \\
\hline \multicolumn{2}{|l|}{ Traditional medicine practices } \\
\hline Practitioners of traditional medicine & 2 \\
\hline Total: & 583 \\
\hline
\end{tabular}

of Potosí complained about the problem of lost screening results: "At the health center the nurse demands that we take the Pap test, but we never get the results, so we do not know anything because they do not show it to us. They only say that they don't have it after a whole year."

Many women who were interviewed mentioned that screening services in urban and periurban areas are easily accessible for those who reside near health care facilities. Although Pap smear services are available in most rural health posts, women from some rural areas reported that they must travel far to these facilities because of large catchment areas. Since diagnostic and treatment services are only available in urban centers, rural women must travel far for management of abnormal conditions. Transportation problems as well as time away from work and family often make these trips difficult and costly. Language also serves as a barrier for some women. Most providers speak just Spanish, while $11.5 \%$ of the population speaks only an indigenous language (13). Many women who have not had Pap smears dismiss screening because of shame, self-consciousness, fear of test results, and perceived social stigma. Pap smears are often associated with sexually transmitted infections.

Organization of services. There is currently no national strategy to achieve the goal of $80 \%$ cervical cancer screening coverage among all women aged 25-49 or to ensure adequate follow-up of screened women. Opportunistic screening is reportedly provided as a component of reproductive health services, but rarely for women attending health facilities for other reasons. This results in many missed opportunities to expand coverage (1). Mobile screening campaigns have been conducted sporadically in some parts of the country, increasing the number of Pap smears performed, but without adequate linkages for follow-up and treatment. At the majority of public sector facilities visited, health personnel estimated that $50 \%$ to $80 \%$ of women who undergo screening are lost to follow-up. Institutional information and tracking systems, coordination of testing and treatment services, and basic logistics for transporting tests to labs and communicating results to providers and women in a timely manner are lacking, except in a small number of facilities. Additionally, the capacity to provide appropriate counseling to clients on the importance of follow-up varies among providers and facilities. Doctors and nurses have not received counseling training, although a few nurses interviewed claimed to provide women with information on cervical cancer prevention and treatment. Providers at NGO clinics were found to be more likely than those at MHSW facilities to give clients information and support, as the public health 
facilities generally did not have trained counselors to discuss cervical cancer prevention.

All the public and private cytology laboratories reported having sufficient staff to cope with the present workload, with each technician processing fewer than 50 slides per day (complying with international guidelines) (14). Bolivia has recently joined the Pan American Cytology Network (Red Panamericana de Citología) (15), which works to improve administrative and technical quality among affiliated laboratories. The Oncology Institute of Eastern Bolivia (Instituto Oncológico del Oriente Boliviano), in the city of Santa Cruz, and the Hospital de Clinicas, in the city of La Paz, are the two Bolivian facilities that belong to the Pan American Cytology Network. These two labs as well as most private labs were found to coordinate slide transport and delivery of results better than other public sector facilities. These labs do this by assigning specific days for these operations to occur, thereby minimizing delays and preventing backlog, reportedly a noticeable problem in other labs. The transport and timely delivery of results was an even greater challenge to health care facilities in rural areas due to more complex logistical issues, such as greater distances from the cytology labs and impassable roads.

Referral systems for women requiring colposcopy and treatment of precancerous lesions were found to be weak or lacking altogether, compounding the already existing deficiency in precancer treatment. There are no established referral networks, and although standard referral and feedback forms exist, they are rarely utilized. It is generally up to the client to inform referring providers of any treatment or follow-up care received. Women suspected of having cervical cancer, however, are more aggressively tracked and referred for additional care than those women whose Pap results denote a precancerous condition. Nevertheless, loss to follow-up is also an issue for women undergoing radiotherapy, with one facility reporting that nearly $50 \%$ of their clients do not complete treatment (Table 4).

Supervision and monitoring. The Women's Cancer Component of the MHSW supervises the public sector cervical cancer prevention and treatment services provided in the departments. Rather than focusing on technical know-how, this supervision concentrates on such logistical and administrative aspects as monitoring the numbers of Pap smears, and campaigns and other prevention activities. There is no monitoring of program results against established indicators such as coverage rates, follow-up of women who screen positive, or compliance of health personnel with national norms.

The reference cytology labs in the cities of $\mathrm{La}$ Paz and Santa Cruz reportedly ensure more rigor-
TABLE 4. Treated cases of precancerous lesions and cancer in one department in Bolivia, 2001

\begin{tabular}{lcccc}
\hline & $\begin{array}{c}\text { Total } \\
\text { no. of } \\
\text { women }\end{array}$ & $\begin{array}{c}\text { No. of } \\
\text { women } \\
\text { treated }\end{array}$ & \multicolumn{2}{c}{$\begin{array}{c}\text { Women with } \\
\text { abnormal results } \\
\text { lost to follow-up }\end{array}$} \\
\hline CIN I & 9 & 4 & 5 & No. \\
CIN II & 48 & $8^{b}$ & 40 & 83 \\
CIN III & 21 & $5^{b}$ & 16 & 76 \\
Invasive cancer & 10 & $8^{\mathrm{c}}$ & 2 & 20 \\
\hline
\end{tabular}

${ }^{a} \mathrm{CIN}=$ cervical intraepithelial neoplasia

b Treatment with hysterectomy.

c Treatment with radiotherapy.

ous quality control through the standardized use of the Bethesda System of classification (16) and external quality assurance as member labs of the Pan American Cytology Network. Internal quality control was reported in all public sector laboratories. However, health care providers who were interviewed noted that they do not receive feedback from the laboratory personnel who assess the Pap smears about the quality of the samples. Overall, there is no system of supervision that encompasses clinical, technical, and service delivery support for cervical cancer prevention and that also includes assessing the quality of the Pap smears taken, quality of the test results, or proficiency of laboratory personnel.

Infrastructure, equipment, and supplies. All the public and private facilities visited are clean and well maintained and have running water and electricity. Appropriate exhaust systems, however, are lacking in most of the laboratories. Where treatment for precancer is available, there is a shortage, for the caseload, of functioning colposcopes and machines for loop electrosurgical excision procedure (LEEP), which is an outpatient technique to remove precancerous tissue. In addition, there are no repair and maintenance systems for this equipment. The oncology units where cervical cancer is managed are equipped with modern technology to treat cervical cancer, but effective pain medications for palliative care, such as morphine, are difficult to obtain because of stringent regulations. These regulations result in a lengthy and involved prescribing or purchasing process, which providers prefer to avoid.

Information systems and cancer registry. The National Health Information System (Sistema Nacional de Información en Salud) is a comprehensive database of health indicators. The National Health Information System collects one statistic related to cervical cancer: the number of Pap smears performed. There are no data on screening coverage rates, the number of women treated for precancer- 
ous conditions, or follow-up rates, which could aid program monitoring and evaluation. There is no standardized system for registering biographical or screening information in the public sector health care facilities and labs, although the MHSW has recently introduced new forms for all service sites to use for this purpose. Providers interviewed said that they never received any orientation on how to use them, therefore they continued to use an array of non-uniform forms and registers. In many MHSW health facilities, client registers were often incomplete and not updated, with the staff describing the documentation process as very labor intensive. Cytology labs used their own forms and identification numbers for each Pap smear processed, precluding any linkage between clinic and lab records to corroborate clinical information and recognize repeat Pap smears performed on the same woman in different facilities.

A computerized information system to record and retrieve information on coverage, laboratory data, follow-up rates, and compliance with treatment has been developed by the Oncology Institute of Eastern Bolivia. Depending on the outcome of pilot tests, the Santa Cruz system could be a prototype for other locales.

There is no national population-based cancer registry or official death certificate in Bolivia, which forces statisticians to estimate mortality data. However, there are independent, population-based cancer registries in Bolivia that cover the cities of $\mathrm{La}$ Paz and El Alto, Oruro and Potosí, and Sucre. According to interviews with MHSW officials, the International Agency for Research on Cancer will be providing technical assistance on the use of a software package to strengthen these cancer registries.

Training and professional development. Medical and nursing schools include theoretical and practical aspects of cervical cancer prevention in the basic curricula, which were designed many years ago. Consequently, recent essential knowledge about the development of cancer has not been incorporated. Bolivia possesses the in-country capacity for training in cytology, colposcopy, and LEEP. However, professional development courses for doctors and nurses on screening, colposcopy, or treatment of precancerous conditions are not offered. Occasional in-service, on-the-job, or short-term special-focus trainings on screening are conducted. In addition, some NGO staff reportedly receive ongoing training in cervical cancer prevention through internships or by attending workshops and conferences.

Knowledge and experience of health personnel. Most providers who were observed as they performed Pap smears were technically adept. How- ever, during interviews, many providers proved not to be aware that Pap smears detect treatable, precancerous lesions. The majority of primary care providers who were interviewed are not aware of the importance of treating precancerous lesions to prevent cancer and of the possibility of using outpatient procedures, such as LEEP and cryotherapy, to treat precancerous lesions. Few gynecologists interviewed are experienced in practicing LEEP and cryotherapy, and they perform hysterectomy instead. Some are trained in LEEP, but none of the interviewed providers is experienced with cryotherapy to treat precancer (17).

Most of the providers and administrators who were interviewed are not aware of the National Norms, Regulations, Protocols and Procedures for the Detection and Control of Cervical Cancer (11). Even among those who are aware of these norms, many of the providers are resistant to the changes in protocol, or they disagree with the target age range and frequency of Pap screening. Most providers and laboratory personnel are not familiar with the Bethesda System of classification, which is recommended by the norms. As a result, a variety of nomenclature is used across the country, likely leading to difficulty comparing cytology results.

Interviews with doctors in the country's four oncology centers affirmed that the physicians are experienced in performing radical hysterectomies, chemoradiation, and radiotherapy. These specialists also conduct palliative surgery and palliative radiotherapy, but they agree that it is important to develop standards for palliative care that include pain management as well as psychosocial and emotional care. (After the fieldwork for this assessment was completed, a multiregional, multidisciplinary team published clinical guidelines for palliative care in Bolivia (18)).

Knowledge and information sources of clients and community members. Most women clients and community members who were interviewed for the assessment have heard of the Pap smear but misunderstand the purpose of the test, the testing procedure, and how frequently it should be performed. They often do not associate Pap smears with cervical cancer prevention, but instead believe the Pap smears are used to diagnose or treat sexually transmitted infections. For instance, one health care facility client in the department of Cochabamba explained that even though she utilizes a local clinic, she has never been educated about cervical cancer: "At the health center they teach us to care for children, to take care of pregnant mothers, but they don't talk about cancer. I heard on the radio that [cervical cancer] is serious, but I don't know how." 
Many women are reportedly ashamed to request the test because of stigmas attached to sexually transmitted infections and concerns about being considered promiscuous. In contrast, a smaller proportion of women seek out Pap smears whenever they have an abnormal discharge because they mistakenly associate the test with the detection of vaginal infections. A common belief among most women interviewed is that cancer always results in death. For example, one woman from the department of La Paz expressed a common sentiment: "If I am going to die, why should I undergo treatment?" The women are not aware that precancerous cervical lesions can be treated, thus preventing cervical cancer and death. Additionally, women explained that they tend to address health problems as they experience physical symptoms and do not tend to use health services for disease prevention.

According to interviews with male community members, most of them do not know about Pap smears, cervical cancer, or the relation between the two. They also do not recognize their potential role as advocates for women's health. This is despite the fact that in some parts of the country such health care decisions as whether or not a woman has a Pap smear are determined by the husband, according to the women and providers interviewed. Knowledge about Pap smears and cervical cancer varies among local government authorities, with most unaware of the potential for treatment of precancerous lesions. However, in the department of Santa Cruz, where much emphasis has been placed on cervical cancer prevention, local authorities are very knowledgeable about the issues and committed to addressing the problem.

Accurate lay information about cervical cancer and its prevention is limited. Informational materials were rarely seen during the assessment, and those that did exist were often outdated. Community health programs and health care providers tend to provide information on other health issues, neglecting cervical cancer. Instead, women who were interviewed identified personal experience and word of mouth as key sources of information about cervical cancer. In rural areas, radio spots are also prime information sources, along with women's groups. Overall, the women interviewed indicated a preference for illustrated over textheavy informational materials.

\section{Technical input workshop}

In May 2002, 60 leaders in cervical cancer prevention, treatment, and policy attended the twoday technical input workshop in order to develop research, policy, and programmatic recommendations for health authorities. The suggestions included developing strategies to improve coordination, implementing norms for cervical cancer screening and treatment within the health system, strengthening existing screening and treatment methods (such as by improving training systems and quality control in laboratories), and implementing projects to pilot information systems to track cervical cancer prevention and client followup activities. Through the workshop, alliances among participants were created and important linkages were formed in order to help resolve the issues identified during the assessment. For example, communication among important national stakeholders in the prevention and treatment of cervical cancer was fortified, a group of oncologists drafted a "manifesto of dedication" to reducing cervical cancer, and alliances among pathologists took root. These relationships are crucial catalysts for improving the quality of cervical cancer services.

\section{DISCUSSION}

Although there were similar findings across the departments where the fieldwork was done, some limitations of this study should be considered. The assessment team was provided Government identification cards, which may have introduced a response bias for any interviewees who perceived that all team members were Government representatives. A selection bias of communities, facilities, and individuals may have been introduced, as the team was unable to visit certain preselected rural and urban sites due to social unrest during the time of the fieldwork. Although many interviews were conducted and valuable contributions made by providers and administrators from all levels of the health system, some key district directors and health providers were unavailable for interviews.

In recognition of the persistent high rates of cervical cancer incidence and mortality in Bolivia, national health authorities have taken initial steps to address the problem by establishing the Women's Cancer Component within the MHSW, developing national screening and treatment norms, and offering free services for screening and treatment of precancerous lesions. However, in order to achieve a substantial impact on morbidity and mortality, interventions must broaden screening coverage of appropriate women, ensure the quality of screening, make treatment of precancer more widely available, guarantee adequate and complete follow-up of women with abnormal screening results, and enable routine monitoring of program targets through a comprehensive information system. 
One of the primary concerns raised by the study findings is that the MHSW's existing cervical cancer prevention and treatment program focuses heavily on screening and not enough on treatment of precancerous conditions to prevent progression to cervical cancer. In order to reduce disease, screening programs must be coupled with treatment services for such conditions. While treatment services of this type exist in a few tertiary facilities, many health care providers do not understand that Pap smears detect treatable, precancerous lesions and that outpatient treatment of these lesions prevents cervical cancer. Health care providers should be updated on this issue, and enough of them should be trained and equipped so as to provide treatment for precancerous lesions in an adequate number of facilities across the country. Bolivia's current approach to and technical capacity for treatment of cervical cancer are adequate. However, treatment compliance must be improved by establishing efficient systems for tracking women with positive screening results. Screening and diagnosis of precancer and cancer without appropriate and complete treatment is of little value in reducing mortality rates.

Despite a screening focus, there is no clear strategy for attaining the MHSW's goal to screen $80 \%$ of women. Women rarely request Pap smears, in part due to a number of obstacles to accessing services and also because of a basic lack of understanding of the purpose of screening. Therefore, opportunities to efficiently broaden screening coverage across the target population must be developed. We recommend efforts that go beyond opportunistic screening, to a system where women accessing care for any health need are able, if eligible, to get a Pap smear. In addition, in order to request services, women and men need accurate information about cervical cancer, the importance of screening, and treatment of precancerous lesions to prevent cervical cancer. Finally, reliable, well-planned, quality services must be available and accessible.

Women in Bolivia are diagnosed with cervical cancer and face death at unnecessarily high rates, despite existing prevention and treatment services. Steps are already being taken to implement the recommendations of this assessment (19). That would contribute to the larger, ongoing strategic process of planning, developing appropriate policy, strengthening cervical cancer prevention services, and bolstering outreach efforts that increase community demand for services. Enacting such strategies will help to reduce the country's burden of disease from cervical cancer. The best hope for cervical cancer prevention worldwide, however, is for an effective prophylactic vaccine against human papillomavirus (HPV), the virus that causes cervical cancer. Such a vaccine is being developed (20). Never- theless, even with access to a vaccine, screening will remain a necessary component of any comprehensive cancer control program for the foreseeable future. For that reason, research into simpler, more cost-effective, more acceptable approaches to screening are currently under way in several countries worldwide (e.g., Peru, South Africa) $(21,22)$. Most notable are methods that use vinegar or iodine solutions and visual inspection by a trained health provider to identify potential abnormalities, and objective tests to detect HPV DNA $(23,24)$. While these approaches are still being evaluated, initial results suggest that they have the potential to save more lives at lower cost than does Pap screening (22). The results from these investigations could have a substantial impact on cervical cancer prevention, benefiting women in Bolivia and other countries around the world.

Acknowledgements. We would like to thank Verónica Kaune for coordinating the assessment; Marcelo Alvarez Ascarrunz, Marcia Arandia de Ramos, Waldo Dávila, Leonor Flores, Ruth Gálvez, Mario Abraham Méndez Ramos, Dolly Montaño, Norma Quispe, Teresa Rivero, and María Luz Terrazas for their tireless participation on the research team; Margarita Díaz and María Dolores Castro for their expert technical assistance; the Departmental Health Services in the cities of Cochabamba, La Paz, Potosí, and Santa Cruz for their help with coordinating site visits; the facilities that allowed us to visit and become familiar with their services; and all the persons who agreed to be interviewed. María Lorencikova provided valuable insight and guidance throughout the project. Finally, we are grateful to Sally Girvin, Jan Bradley, Victor Conde, and Susana Asport for their input on previous drafts of this manuscript. Funding for this assessment was provided by the Bill \& Melinda Gates Foundation through the Alliance for Cervical Cancer Prevention.

\section{SINOPSIS}

\section{Evaluación participativa orientada a identificar estrategias para mejorar la prevención y el tratamiento del cáncer cervicouterino en Bolivia}

En este trabajo se evalúan la organización y disponibilidad de servicios de prevención y tratamiento del cáncer cervicouterino en cuatro de los nueve departamentos de Bolivia y se identifican estrategias de intervención. De 2001 a 2002 un equipo multidisciplinario de 15 personas llevó a cabo en Bolivia una evaluación que comprendió una revisión bibliográfica sobre el cáncer cervicouterino en el país, entrevistas 
semiestructuradas con 583 partes interesadas y 56 observaciones de servicios de salud de diversos niveles. En un taller celebrado después del trabajo de campo se reunieron 60 líderes de todos los departamentos del país para revisar los resultados y determinar su prioridad, y para elaborar recomendaciones basadas en las pruebas científicas recaudadas con miras a fortalecer los servicios de prevención del cáncer cervicouterino.

Bolivia tiene una de las tasas más altas de cáncer cervicouterino en el mundo. No obstante, no tiene ningún programa organizado ni tampoco ninguna estrategia destinada a lograr que el tamizaje del cáncer cervicouterino alcance una cobertura mínima de $80 \%$, que es la meta establecida por el Ministerio de Salud y Previsión Social. Una buena parte de la población carece de información sobre los servicios para la prevención y el tratamiento de lesiones precancerosas, o no puede llegar a estos servicios con facilidad. Los proveedores de atención sanitaria en el sector público calculan que de 50 a $80 \%$ de las mujeres sometidas al tamizaje no regresan a su seguimiento porque no hay ningún sistema que garantice un seguimiento adecuado con fines de diagnóstico o tratamiento. Muchos prestadores de atención de salud desconocen que los frotis de Papanicolaou se usan para detectar lesiones precancerosas.
Bolivia tiene una unidad establecida dentro del Ministerio de Salud y Previsión Social cuya función es crear, administrar y supervisar programas nacionales para la prevención y el tratamiento del cáncer cervicouterino. Dicha unidad, en coordinación con las autoridades sanitarias en cada uno de los departamentos del país, también busca fortalecer la imposición de normas nacionales, actividades de capacitación, e iniciativas comunitarias de tipo informativo o educativo. No obstante, los servicios de tamizaje no están debidamente vinculados con los de diagnóstico y tratamiento de lesiones precancerosas. Por añadidura, los servicios de diagnóstico y tratamiento no siempre abundan o son accesibles. Si se han de mejorar los servicios y la atención a la comunidad, es necesario llevar a cabo investigaciones, efectuar cambios programáticos y adoptar cambios de políticas a fin de fortalecer la planificación y el proceso decisorio en conexión con los aspectos administrativos, tecnológicos, socioculturales y económicos del asunto.

Palabras clave: neoplasmas del cuello uterino; servicios de salud para mujeres; servicios de salud preventiva; conocimientos, actitudes y práctica en salud; Bolivia.

\section{REFERENCES}

1. Robles SC, White F, Peruga A. Trends in cervical cancer mortality in the Americas. Bull Pan Am Health Organ. 1996; 30(4):290-301.

2. Ferlay J, Bray F, Pisani P, Parkin DM. GLOBOCAN 2000: cancer incidence, mortality and prevalence worldwide [CD-R0M]. Version 1.0. Lyon: IARCPress; 2001. (IARC CancerBase No. 5).

3. Kinney W, Sung HY, Kearney KA, Miller M, Sawaya G, Hiatt RA. Missed opportunities for cervical cancer screening of $\mathrm{HMO}$ members developing invasive cervical cancer (ICC). Gynecol Oncol. 1998;71(3):428-30.

4. Bishop A, Sherris J, Tsu VD, KilbourneBrook M. Cervical dysplasia treatment: key issues for developing countries. Bull Pan Am Health Organ. 1996;30(4):378-86.

5. Pan American Health Organization. Bolivia. In: Health in the Americas, 2002 edition. Volume II. Washington, D.C.: PAHO; 2002. Pp. 85-97.

6. Bolivia, Ministerio de Salud y Previsión Social. Sistema Nacional de Información en Salud [Web page]. Available from: http://www.sns.gov.bo. Accessed 15 November 2001.

7. Spicehandler J, Simmons R. Contraceptive introduction reconsidered: a review and conceptual framework. Geneva: World Health Organization; 1994.

8. World Health Organization. Making decisions about contraceptive introduction: a guide for conducting assessments to broaden contraceptive choice and improve quality of care. Geneva: $\mathrm{WHO}$ 2002.
9. Bruce J. Fundamental elements of quality of care: a simple framework. Stud Fam Plann. 1990;21(2):61-91.

10. Huezo C, Diaz S. Quality of care in family planning: clients' rights and providers' needs. Adv Contracept. 1993;9(2):129-39.

11. Bolivia, Ministerio de Salud y Previsión Social, Unidad Nacional de Atención a las Personas. Norma nacional, reglas, protocolos y procedimientos para la detección y control de cáncer de cuello uterino. La Paz: MSPS; 2001

12. Bolivia, Ministerio de Salud y Previsión Social. Plan Bolivia: Seguro Universal Materno Infantil [Internet site]. Available from: http://www.sns.gov.bo/ seguro/sumi. Accessed 20 June 2003.

13. Bolivia, Ministerio de Planeamiento y Coordinación, Instituto Nacional de Estadística. Censo nacional de población y vivienda (CNPV) 1992. La Paz: MPC; 1993.

14. Quality Management Program-Laboratory Services. Standards of practice guidelines: gynecologic cytology. Toronto: Ontario Quality Assurance Program in Gynecologic Cytology; 2000.

15. Pan American Health Organization. Pan American Cytology Network: an operations manual. Washington, D.C.: PAHO; 2001.

16. Solomon D, Davey D, Kurman R, Moriarty A, O'Connor D, Prey M, et al. The 2001 Bethesda System: terminology for reporting results of cervical cytology. JAMA. 2002;287(16):2114-9.

17. Sherris J, Herdman C. Preventing cervical cancer in low-resource settings. Outlook. 2000;18(1):1-8.
18. Bolivia, Ministerio de Salud y Previsión Social. Guías de práctica-clínica oncológica. La Paz: MSPS; 2002.

19. Bolivia, Ministry of Health and Social Welfare/Component for the Detection and Control of Women's Cancer; Engender Health; Pan American Health Organization. Cervical cancer prevention and treatment services in Bolivia; a strategic assessment. New York: EngenderHealth; 2003.

20. Koutsky LA, Ault KA, Wheeler CM Brown DR, Barr E, Alvarez FB, et al. A controlled trial of a human papillomavirus type 16 vaccine. $N$ Engl J Med. 2002;347(21):1645-51.

21. Denny L, Kuhn L, Pollack A, Wainwright $\mathrm{H}$, Wright Jr TC. Evaluation of alternative methods of cervical cancer screening for resource-poor settings. Cancer. 2000;89(4):826-33.

22. Goldie S, Kuhn L, Denny L, Pollack A, Wright T. Policy analysis of cervical cancer screening strategies in low-resource settings. JAMA. 2001;285(24):3107-15.

23. Sankaranarayanan $R$, Wesley $R$, Thara $S$, Dhakad N, Chandralekha B, Sebastian $P$, et al. Test characteristics of visual inspection with $4 \%$ acetic acid (VIA) and Lugol's iodine (VILI) in cervical cancer screening in Kerala, India. Int J Cancer. 2003;106(3):404-8

24. Schiffman M, Herrero R, Hildesheim A Sherman ME, Bratti M, Wacholder $S$, et al. HPV DNA testing in cervical cancer screening: results from women in a high-risk province of Costa Rica. JAMA. 2000;283(1):87-93. 